thinks, as successive modifications of each other; but the next release is an entirely independent form, having no relation to the other.

(5) The Mongolian Release.-In this the string is drawn by the flexed thumb bent over the string, the end of the forefinger assisting in holding the thumb in position (Figs. 7 and 8). The arrow is held at the junction of the thumb and forefinger, the base of the finger pressing the arrow against the bow. For this reason the arrow is always placed to the right of the bow vertical. This release is characteristic of the Asiatic races, such as the Manchu, Chinese, Corean, Japanese, and Turk. The Persians also use it. The thumb is protected by a guard: the Manchus, Chinese, and others use a thick ring worn near the base of the thumb. It may be made of any hard material, such as horn, bone, ivory, quartz, agate, or jade. The Japanese archer uses a glove consisting of the thumb and two fingers.

These are the principal and most efficier.t forms of redease, although doubtless there are others. Of the methods employed by ancient peoples, as reprcsented in manuscripts, sculptures, \&c., the Assyrians at one stage of their history appear to have used the primary form, while subsequently they used the secondary, and still later the Mediterranean release. The ancient Egyptians appear to have practised three, if not four, definite and distinct methods of release, but many of the representations in the old sculptures are evidently purely conventional, while some are clearly impossible. Following on these, Prof. Morse discusses the methods employed in ancient Greece, Persia, Japan, China, India, Mcxico. Here he is naturally on less secure ground, for he has to endeavour to spell out a conclusion from various and conflicting positions of the hand in various ancient graphic representations of dife amongst these peoples. The discussion involves a considerable amount of cetail and numerous woodcuts by way of illustration, for which the reader must be referred to Prof. Morse's pamphlet. We must content ourselves with reproducing briefly his conclusions, which, it will be understood, are at present for the most part provisional, pending additional information and wider discussion. The persistence of a particular release in a people is well illustrated in the case of the Ainos. For centuries the Ainos have battled with the Japanese, and must have been mindful of the superior archery of their enemies ; indeed, on all hands, with the exception possibly of the Kamchatdales to the north, the Ainos have been surrounded by races practising the Mongolian release, and yet have adhered to their primitive methods of shooting. The two strongest releases-both perhaps equally powerful-are the Mediterranean and Mongolian, and it is interesting to note that the two great divisions of the human family who can claim a history, and who have been dominant in the affairs of mankind, are the Mediterranean nations and the Mongolians. For several thousands of years each stock has had its peculiar arrow-release, and this has persisted through all the mutations of time to the present day. Language, manners, customs, religions, have in the course of centuries widely separated these two great divisions into nations. Side by side they have lived; devastating wars and wars of conquest have marked their contact; and yet the apparently trivial and simple act of releasing the arrow from the bow has remained unchanged. At the present moment the European and Asiatic archer, shooting now only for sport, practise each the release which characterised their remote ancestors. The following classified list shows in a gencral way that the primary, secondary, and tertiary releases are practised by savage races to-day, as well as by certain ancient civilised races, while the Mediterranean and Mongolian releases, though originating early in time, have always characterised the civilised and dominant races. The exceptions to this generalisation are curious : the Little Andaman Islanders practise the Mediterranean release, and those of the Great Andamans the Tertiary various groups of Eskimo practise the Mediterranean release, and have designed a distinct form of arrow for this method.

Primary Release.-Savage: Ainos, Demerara Indians, various North American tribes; civilised : early Assyrian, Egyptian, and Grecian (?)

Secondary Release.-Savage: some North American tribes ; civilised : later Assyrian and Indian (?)

Tertiary Release.-Savage: North American tribes, Great Andamans ; civilised : Siamese, Egyptian, Grecian, and Mexican (?)

Mediterranean Release.-Savage : Eskimo, Little Andamans ; civilised : European nations now, and the archers of the Middle Ages, later Assyrian, early Egyptian, Arabian, Indian, and Roman.

Mongolian Release. - Manchus, Chinese, Coreans, Japanese, Turks, Persians, Scythians, Egyptians(?)

In conclusion, Prof. Morse expresses a belief that the method of using the bow may form another point in establishing or disproving relationships, in identifying the affinities of past races. Travellers and explorers should not con. tent themselves with observing the simple fact that such and such people use bows and arrows, but they should accurately record (I) the attitude of the shaft hand; (2) whether the bow is held horizontally or vertically; (3) whcther the arrow is to the right or left of the buw vertical; and (4) whether the extra arrows are carried in the bow hand or shaft hand. The method of bracing the bow is of importance also. While anxious to get information respecting the arrow-releases of tribes and peoples, he is particularly desirous of hearing about those employed by the Veddahs of Ceylon, the hill-tribes of India, African tribes, and those of South America, especially the Fuegians. Such material, in the shape of descriptions, photographs, drawings, and if possible specimens of bows and arrows, may be sent to Prof. E. S. Morse, Peabody Academy of Science, Salem, Massachusetts, and will be acknowledged and used in a future publication on the subject.

\section{CLIMATOLOGY OF THE CROYDON DISTRICT ${ }^{1}$}

IN a little tract of thirty-six pages, which has just appeared in the Transactions of the Croydon Microscopical and Natural History Club, Mr. Eaton has discussed the climatology of this part of England with a skill, clearness, and fairness seldom met with in local climatologies. The observations of temperature, which were conducted on the same systematic plan with Stevenson's screens, were made at scven stations, these being, in the order of their heights, Park Hill, Addiscombe, South Norwood, West Norwood, Waddon, Wallington, and Beddington. The periods selected for discussion are the five ycars I88 I to 1885 inclusive. The stations are included within an area measuring 4 miles from northea-t to south-west by $2 \frac{1}{2}$ miles from south-east to northwest. The monthly results are given on fourteen pages with satisfactory fullness; and with them are conjoined, for the sake of comparison, the corresponding records of temperature at the Greenwich and Kew Observatories.

The heights and mean temperatures of the five stations from which observations are available for the whole of the five years are these:-Beddington, I 02 feet, $48^{\circ} \cdot 8$; Waddon, I 56 feet, $49^{\circ} \circ$; South Norwood, 190 feet, $49^{\circ} 4$; Addiscombe, 202 feet, $49^{\circ} 3$; and Park Hill, 259 feet, $49^{\circ} 4$, -Park Hill, the highest station, being thus 0.6 warmer than Beddington, the lowest station. This subversion of the general rule that the temperature diminishes with greater elevation is shown to be due to the frequency with which, on clear calm nights, the air in contact with the ground is cooled and rendered denser by radiation, I "Report on the Temperature and the Rainfall of the Croydon District, r88 185 ," by Henry Storks Eaton. 
and thereafter descends to the low-lying grounds of the valleys, displacing the warmer air below. During the unusually dry clear months of January and July I83I the mean temperature of Park Hill exceeded that of Beddington by $3^{\circ} .5$ and $2^{\circ}, 5$ respectively. Hence the first three of the five stations which are on sloping ground have, though at greater elevations than the other two stations below, higher mean temperatures.

This peculiarity in the distribution of the night and the winter temperature becomes the more intensified as the valley is deeper and its sides steeper, and as calms and light winds prevail. Thus at Klagenfurt, situated in one of the valleys of the Tyrol, the mean temperature of January is $20^{\circ} \%$, whereas at the station of Obergipfel, about seven miles distant and 4270 feet higher, the mean for the same month is $19^{\circ} 9$, being thus less than a degree lower than that of Klagenfurt. The subject is one that has seldom received the earnest attention it deserves, particularly in drawing the isothermals of the globe. The Croydon Club would make a clear addition to their observing-system if new stations were established on knolls in the valley of the Wandle for the further prosecution of this inquiry.

The means of temperature from Greenwich and Kew would have had real value in this inquiry if Mr. Eaton could have availed himself of observations made at these Observatories with thermometers exposed in the Stevenson screen. But, as pointed out, the different modes of exposing the thermometers render the results of the three systems of observing incomparable inter se. Thus the mean of the daily highest temperature of August for the five years is $72^{\circ} .5$ for Greenwich, and $69^{\circ} \cdot 5$ for Kew.

The rainfall has been far more extensively observed in the district, the returns of no fewer than seventy stations being available. Grouping the stations according to height, the annual amounts at stations below 200 feet show a mean of 23.27 inches; 200 to 400 feet, 25.39 inches; 400 to 600 feet, 29.12 inches; 600 to 800 feet, $3 I^{\circ} 66$ inches; and above 800 feet, $31 \cdot 36$ inches. The largest amounts of rain occur not on the ridge of the North Downs, but some distance on the lee-side in regard to the prevalent rainy south-westerly winds ; and the amount at like elevations seems also to diminish from west to east. As regards the monthly rainfall, the depth is greater in the upper groups; but the ratios of the monthly to the annual fall show that in spring, but more particularly in summer, there falls proportionally a larger amount of rain in the lower group of stations, whose average elevation is 193 feet. The relatively large increase in the summer rainfall over low-lying plains is one of the most striking facts in the geographical distribution of the rainfall, and is probably due to the physical causes concerned in the development of thunderstorms.

\section{NOTES ON THE RECENT SWARMING OF APHIDES} $\mathrm{HE}$ immediate cause of the sudden appearance of
clouds of insects in certain localities is not very apparent, but it may be surmised that the predominance or scarceness of their natural insect foes has much control over the phenomenon; added to which must be taken into account the effects of weather and temperature. A few days ago I had a notice from an obliging Birmingham correspondent, Mr. George Baker, who kindly furnished me with the following particulars:-

On October 5 the town of Mansfield, on the borders of Sherwood Forest, was visited by a cloud of Aphides, which swarmed in the town and over the country round, across an area of many miles. The town was visited "literally by millions; every one, as they walked along, waving their handkerchiefs or newspapers before their faces to avoid inhaling the insects. ... Wet paint was covered by a mass of these black Aphides." This swarm continued with decreasing numbers throughout five days, and heavy rain during part of this time did not seem much to affect them. On the road to Nottingham these insects were noticed as engaged in singular gyrations and unclulatory dances above the tops of the spruce-firs, there forming dense pyramidal columns.

A similar cloud, but less remarkable as to numbers, was observed about the same time at Birmingham; which, however, as the town must be at least 50 miles distant, can be scarcely considered as forming a part of this same swarm. Possibly similar causes operated to produce the like pheno:nenon in both places.

These insects proved on examination to be Rhopalosiphum dianthi of Schrank, which is identical with Aphis persice of Morren, and A. rapa of Curtis, and $A$. vastator of Smee. It is a veritable pest in some years, doing considerable damage to turnip, mangel, and other crops, and in our gardens injuring our peach-trees. This present notice of its swarming is, however, by no means unprecedented.

In September and October I834 Morren noted an immense swarm all over Belgium, and states his belief that it came across the sea from England. He says they obscured the light of day, and covered the walls of the houses so as partially to conceal them. Gilbert White notes that in August I 785 the people of Selborne were surprised by a swarm of "smother flies." Those that were walking in the street found themselves covered with these insects, which blackened the hedges and vegetables round. White thought these might be emigrations from the hop-gardens of Kent and Sussex, and from those near Farnham. If so, the species differs from the insects above noticed.

The ehoice of high objects to dance over is not confined to Aphides, e.g. many of the Tipulidre. The singular persistent dance of Anthomyia meteorica over the heads of horses is familiar to all.

G. B. BUCKTON

\section{NOTES}

A MosT attractive group of birds has just been. placed by Prof. Flower in the great hall of the Natural History Museum at South Kensington. The case is intended to illustrate the hybridisation of species in a state of nature, and the species selected are the hooded and carrion crows (Corvus cornix and C. corone) and the European and Asiatic goldfinches (Carduelis elegans and $C$. orientalis). The series of these birds has been presented to the Museum by Mr. Henry Seebohm, who procured the specimens himself during his travels in Siberia. The case of the crows is one of the few instances known of actual wild hybridisation, though many more are suspected, especially among the game birds. It is certain, however, that wherever the colonies of hooded crows meet the carrion crow throughout the Palæarctic region the two species interbreed freely, and the result is shown in the young, the gray saddle-back of the hooded crow exhibiting a considerable admixture of black owing to the strain of C. corone in the parentage. The case of the goldfinches is not quite so completely proved, but is apparently a parallel instance of hybridisation. The British Museum has been for some time indebted to Mr. Seebohm for very valuable presents of birds, which have been mounted in the bird-galleries. Not long ago he gave a specimen of Ross's gull (Rhodustethia rossi), one of the rarest of the Larida, and a species which was a desideratum to the national collection. He presented also, last year, a fine case of Steller's sea-eagle (Haliaitus pelagicus) from Kamchatka.

THE Geodetic Conference began its meetings in Berlin last week. The countries represented are Belgium, by two delegates; Denmark, by one; Germany, by fourteen, including Prof. Dr. Förster, of the Royal Observatory, Prof. Helmholtz, 